\title{
Nijmegen Breakage Syndrome-Like Disorder
}

National Cancer Institute

\section{Source}

National Cancer Institute. Nijmegen Breakage Syndrome-Like Disorder. NCI Thesaurus.

Code $C 153178$.

A condition caused by mutation(s) in the RAD50 gene, encoding DNA repair protein

RAD50. It is characterized by microcephaly and chromosomal instability. 